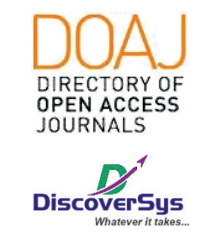

Published by DiscoverSys

\section{Karakteristik temuan radiologis pada pasien low back pain di RSUP Sanglah Denpasar periode Maret 2016-Oktober 2017}

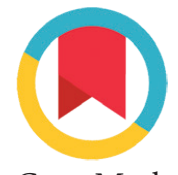

CrossMark

\author{
Komang Mila Triana Sari, ${ }^{1 *}$ Elysanti Dwi Martadiani, ${ }^{2}$ Made Widhi Asih²
}

\section{ABSTRACT}

Background: Low back pain (LBP) is a common problem in almost all parts of the world. It may cause disability and a huge social and economic burden in the community. Radiological examination is often necessary to help the doctor in evaluating LBP. Aim: The study aims to find out the radiological characteristics of $L B P$ as a preventive effort against those case. Method: The study was descriptive cross-sectional design involved 65 LBP patients as study respondents in Sanglah General Hospital from March 2016-0ctober 2017.

Result: Characteristics of LBP patients are male patients and patients aged 50-59 years. Both are the most frequent sample which were found out in the study.

Conclusion: The most common radiological findings in each examination modality are as follows: osteophytes on Radiographic examination, burst fracture, compression fracture and fractures of spinous process on CT scan, and spinal canal stenosis on MRI examination.

Keywords: LBP, radiological finding, Radiography, CT Scan, MRI

Cite This Article: Sari, K.M.T., Martadiani, E.D., Asih, M.W. 2019. Karakteristik temuan radiologis pada pasien low back pain di RSUP Sanglah Denpasar periode Maret 2016-0ktober 2017. Intisari Sains Medis 10(1): 43-47. D0I: 10.1556/ism.v10i1.235

\title{
ABSTRAK
}

Low back pain (LBP) merupakan masalah umum yang sering terjadi hampir di seluruh belahan dunia, bisa menyebabkan disabilitas dan terjadinya beban sosial dan ekonomi yang sangat besar di komunitas. Pemeriksaan radiologi sering diperlukan untuk membantu dokter mengetahui penyebab timbulnya keluhan nyeri punggung bawah.

Tujuan: Untuk mengenali karakteristik radiologis LBP sebagai usaha untuk mencegah bertambahnya kasus dan komplikasi LBP khususnya di Bali.

Metode: Penelitian ini menggunakan studi deskriptif cross-sectional. Penelitian ini dilakukan di RS Sanglah Denpasar pada rentang waktu
Maret 2016 - Oktober 2017. Data penelitian adalah data sekunder dari rekam medis pasien. Pada penelitian ini, terdapat sebanyak 65 pasien LBP sebagai responden penelitian. Hasil: Karakteristik sampel terbanyak pada pasien LBP adalah pasien dengan jenis kelamin lakilaki dan pasien yang berusia 50-59 tahun.

Kesimpulan: Temuan radiologis yang paling sering ditemukan pada masing-masing modalitas pemeriksaan adalah sebagai berikut: osteofit pada pemeriksaan Radiografi, burst fracture, fraktur kompresi dan fraktur prosessus spinosus pada pemeriksaan CT Scan, dan spinal canal stenosis pada pemeriksaan MRI.
'Program Studi Pendidikan Dokter, Fakultas Kedokteran, Universitas Udayana

${ }^{2}$ Bagian/SMF Radiologi Fakultas Kedokteran, Universitas Udayana Rumah Sakit Umum Pusat Sanglah Denpasar

*Corresponding:

Komang Mila Triana Sari, Program Studi Pendidikan Dokter, Fakultas Kedokteran, Universitas Udayana milatriana3105@gmail.com

Received: 2018-04-08 Accepted: 2018-06-17 Published: 2019-04-01
Kata Kunci: LBP, temuan radiologis, Radiografi, CT Scan, MRI

Cite Pasal Ini: Sari, K.M.T., Martadiani, E.D., Asih, M.W. 2019. Karakteristik temuan radiologis pada pasien low back pain di RSUP Sanglah Denpasar periode Maret 2016-0ktober 2017. Intisari Sains Medis 10(1): 43-47. D0I: 10.1556/ism.v10i1.235

\section{PENDAHULUAN}

Nyeri punggung bawah atau low back pain (LBP), keluhan sakit punggung di daerah lumbal, merupakan masalah umum yang sering terjadi hampir di seluruh belahan dunia, bisa menyebabkan disabilitas dan terjadinya beban sosial dan ekonomi yang sangat besar di komunitas. ${ }^{1} \mathrm{Hal}$ ini dapat disebabkan oleh banyak masalah seperti melakukan aktivitas dengan gerakan yang mendadak yang melebihi batas kemampuan sendi dan otot, mengangkat beban berat dalam jangka waktu yang terlalu lama, postur tubuh yang buruk (seperti misalnya membungkuk), iritasi, trauma, dan sebagainya. ${ }^{2}$

The 2010 Global Burden of Disease Study memperkirakan bahwa nyeri punggung bawah berada di antara 10 penyakit dan cedera yang paling sering terjadi. ${ }^{3}$ Pemeriksaan radiologi sering diperlukan untuk membantu dokter mengetahui penyebab dari timbulnya keluhan nyeri punggung bawah dan selanjutnya hal ini penting untuk merencanakan terapi bagi pasien. Imaging dianjurkan 
untuk dilakukan sesuai indikasi klinis atau red flag yang terdiri dari trauma terkait dengan umur (jejas akibat kecelakaan, jejas akibat jatuh minor pada pasien osteoporosis), adanya penurunan motoris dan sensoris secara progresif, adanya inkontinensia atau retensi urin yang baru, saddle anesthesia, infeksi spinal dan adanya metastasis kanker ke tulang. ${ }^{4}$ American College of Physician (ACP) dan American Pain Association (APS) merekomendasikan untuk melakukan imaging apabila terdapat gejala yang berat dan defisit neurologis yang progresif. ${ }^{5}$ Imaging dikatakan tidak meningkatkan hasil klinis apabila dilakukan tanpa indikasi yang sesuai, selain itu imaging seringkali memberikan hasil positif palsu seiring dengan peningkatan umur pasien. Akan tetapi imaging diperlukan dalam diagnosis LBP karena pemeriksaan laboratorium untuk LBP kurang spesifik dalam menentukan diagnosis. ${ }^{4}$ Selain itu, pemeriksaan imaging rutin dikatakan dapat menurunkan tingkat kecemasan pasien terkait LBP secara signifikan serta memberikan kepuasan terhadap pasien. ${ }^{5}$

Menentukan karakteristik LBP dari pemeriksaan radiologis merupakan hal yang masih sulit untuk dilakukan. Hal ini dapat disadari dari tidak adanya gold standard radiologis untuk pemeriksaan LBP. Di Indonesia khususnya di Bali belum ada pencatatan khusus mengenai karakteristik standar yang diperlihatkan pada pemeriksaan imaging pasien LBP. Berangkat dari latar belakang yang telah dijelaskan di atas, penulis melihat adanya urgensi untuk membahas mengenai karakteristik radiologis LBP. Penelitian ini penting untuk dilakukan sebagai data dasar untuk mengenali karakteristik radiologis LBP sebagai usaha untuk mencegah bertambahnya kasus dan komplikasi LBP khususnya di Bali.

\section{METODE}

Rancangan penelitian yang digunakan pada penelitian ini adalah penelitian cross-sectional descriptive. Penelitian ini dilakukan di RS Sanglah Denpasar dengan sampel penelitian yaitu pasien LBP yang memenuhi kriteria inklusi. Kriteria inklusi sampel adalah pasien LBP dewasa yang terdiagnosis LBP secara klinis dan dirujuk melakukan pemeriksaan radiologi, sedangkan kriteria eksklusi sampel adalah pasien LBP dengan data gambaran radiologi yang tidak lengkap. Penelitian ini menggunakan semua sampel yang memenuhi kriteria inklusi dan berada pada periode Maret 2016 - Oktober 2017. Data yang digunakan merupakan data sekunder yaitu diperoleh dari rekam medis pasien LBP di bagian Radiologi RSUP Sanglah Denpasar. Data yang terkumpul kemudian dicatat dan diolah secara statistik deskriptif untuk dihitung persentase karakteristik gambaran radiologi pada masing-masing modalitas imaging.

\section{HASIL}

Jumlah sampel pada penelitian ini adalah 65 sampel. Data dianalisa secara deskriptif dan disajikan dalam bentuk table distribusi frekuensi untuk menggambarkan karakteristik temuan radiologi pasien LBP dengan riwayat trauma maupun non trauma pada masing-masing modalitas imaging yaitu Radiografi, CT Scan, dan MRI.

Berdasarkan data sosiodemografi, terdapat perbedaan proporsi jumlah sampel laki-laki yaitu $56,9 \%$ sedangkan jumlah sampel perempuan yaitu $43,1 \%$. Penelitian ini juga memiliki variasi rentangan umur antara $<20$ tahun sampai $>70$ tahun. Distribusi responden terbanyak berada

\section{Tabel 1 Karakteristik sampel pasien LBP di RSUP Sanglah}

\begin{tabular}{lcc}
\hline & \multicolumn{2}{c}{ Jumlah (n=65) } \\
\cline { 2 - 3 } Karakteristik & Frekuensi (n) & Proporsi (\%) \\
\hline Jenis Kelamin & 37 & 56,9 \\
Laki-laki & 28 & 43,1 \\
Perempuan & & \\
Umur & 1 & 1,5 \\
$<20$ tahun & 3 & 4,6 \\
$20-29$ tahun & 10 & 15,4 \\
$30-39$ tahun & 12 & 18,5 \\
$40-49$ tahun & 19 & 29,2 \\
$50-59$ tahun & 13 & 20,0 \\
$60-69$ tahun & 7 & 10,8 \\
$\geq 70$ tahun & & \\
\hline
\end{tabular}




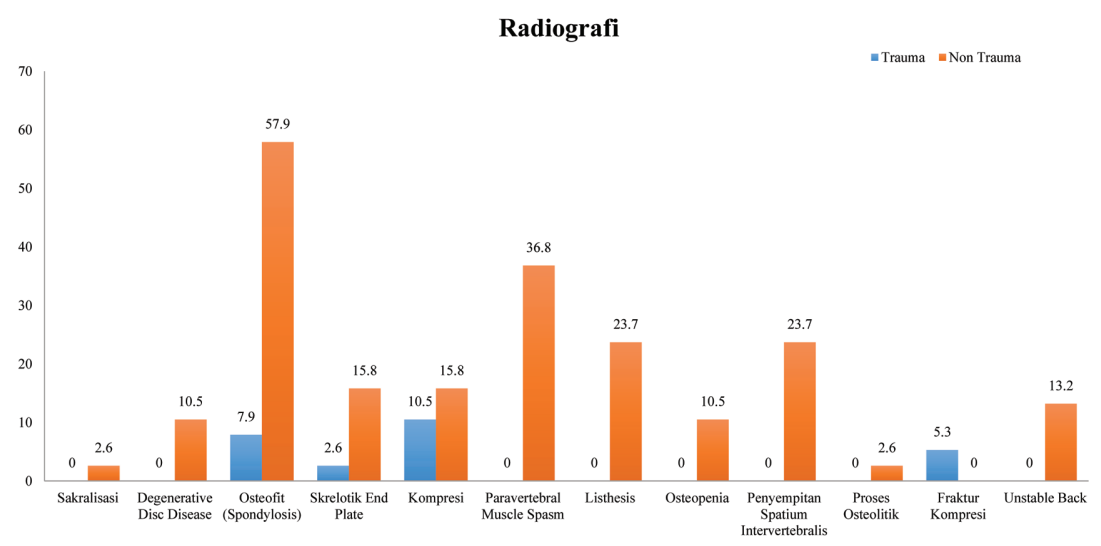

Grafik 1 Diagram batang distribusi proporsi temuan radiologi pada pemeriksaan radiografi

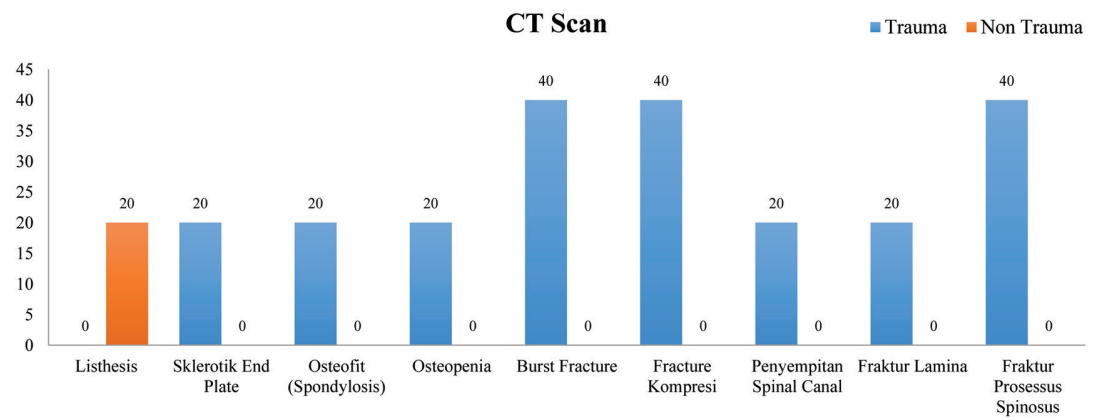

Grafik 2 Diagram batang distribusi proporsi temuan radiologi pada pemeriksaan CT Scan

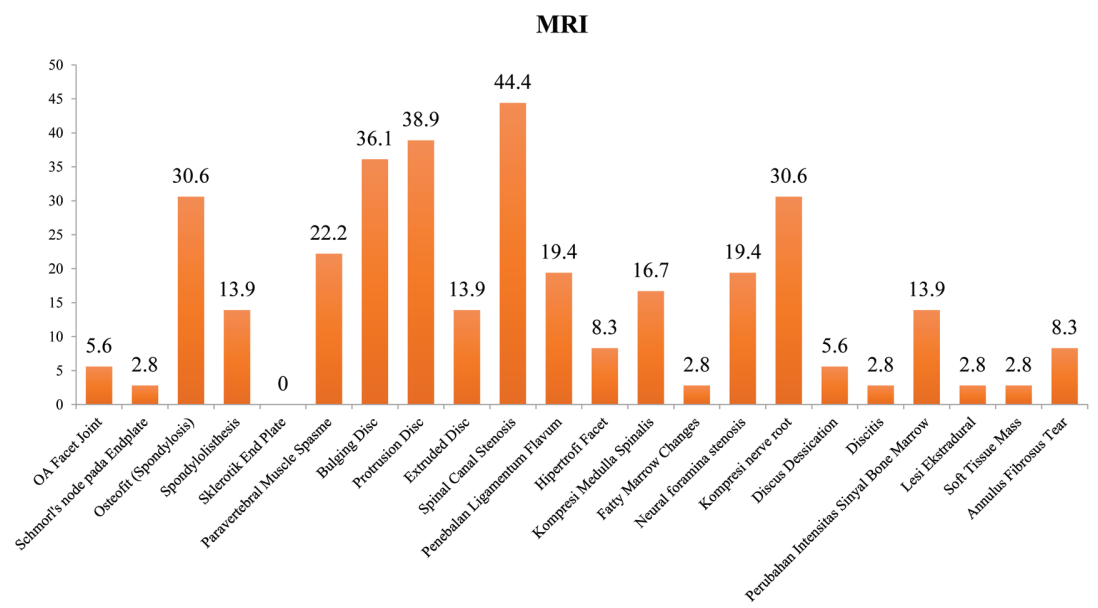

Grafik 3 Diagram batang distribusi proporsi temuan radiologi pada pemeriksaan MRI

pada kelompok umur 50-59 tahun yaitu sebesar 19 orang (29,2\%), sedangkan kelompok umur dengan jumlah respondenpaling sedikit yaitu pada kelompok umur $<20$ tahun sebesar 1 orang $(1,5 \%)$, kelompok umur 20-29 tahun sebesar 3 orang $(4,6 \%)$, kelompok umur $\geq 70$ tahun sebesar 7 orang $(10,8 \%)$, kelompok 30-39 tahun sebesar 10 orang (15,4\%), kelompok umur 40-49 tahun sebesar 12 orang $(18,5 \%)$, dan kelompok umur $60-69$ orang sebesar 13 orang (20\%).
Berdasarkan hasil penelitian ini, didapatkan temuan radiologi terbanyak dengan modalitas Radiografi pada pasien LBP dengan riwayat trauma adalah kompresi yaitu sebesar $10,5 \%$ dan hasil temuan lainnya meliputi osteofit $(7,9 \%)$, fraktur kompresi (5,3\%), dan sklerotik end plate $(2,6 \%)$. Sedangkan pada pasien LBP non trauma, didapatkan hasil temuan radiologi terbanyak yaitu osteofit sebesar 57,9\%. Hasil temuan radiologi lainnya meliputi paravertebral muscle spasm sebesar 14 orang $(36,8 \%)$, listhesis dan penyempitan spatium intervertebralis masing-masing sebesar 9 orang $(23,7 \%)$, sklerotik end platedan kompresi masing-masing sebesar 6 orang $(15,8 \%)$, unstable back sebesar 5 orang $(13,2 \%)$, degenerative disc disease dan osteopenia masing-masing sebesar 4 orang (10,5\%), serta sakralisasi dan proses osteolitik masing-masing sebesar 1 orang $(2,6 \%)$.

Pada modalitas pemeriksaan CT Scan, hasil radiologi terbanyak yang ditemukan pada pasien LBP dengan riwayat trauma adalah burst fracture, fraktur kompresi, dan fraktur prosesus spinosus masing-masing sebesar $40 \%$. Temuan lainnya meliputi sklerotik end plate, osteofit, osteopenia, penyempitan spinal canal, dan fraktur lamina masing-masing sebesar 1 orang (20\%). Sedangkan pada pasien LBP non trauma hanya ditemukan gambaran listhesis sebesar 20\%.

Pada pemeriksaan dengan MRI pada pasien LBP non trauma, temuan radiologi terbanyak adalah gambaran canal stenosis yaitu sebesar $44,4 \%$. Hasil radiologis lain yang juga cukup banyak ditemukan antara lain protrusion $(38,9 \%)$, bulging disc (36,1\%), osteofit dan kompresi nerve root masing-masing sebesar $28,9 \%$. Temuan lainnya antara lain paravertebral muscle spasme $(22,2 \%)$, penebalan ligamentum flavum dan neural foramina stenosis masing-masing sebesar 19,4\%, kompresi medulla spinalis sebesar $(16,7 \%)$, spondylolisthesis, extruded disc, dan perubahan intensitas sinyal bone marrow masing-masing sebesar $13,9 \%$, hipertrofi facet dan annulus fibrosus tear masing-masing sebesar $8,3 \%$, OA facet joint dan discus dessication masing-masing sebesar 5,3\%, dan schmorl's node, penyempitan foramen, fatty marrow, penekanan foramina neuralis, discitis, lesi ekstradural, dan soft tissue mass masing-masing sebesar 2,8\%.

\section{PEMBAHASAN}

Pada sampel penelitian ini ditemukan perbedaan proporsi pasien LBP berdasarkan jenis kelamin yaitu laki-laki sebesar 57\% dan perempuan sebesar $43 \%$. Walaupun terdapat perbedaan proporsi antara laki-laki dan perempuan, namun masih dapat dikatakan antara laki-laki dan perempuan sama-sama memiliki resiko LBP. Tingginya resiko laki-laki 
mengalami LBP dapat dikaitkan dengan pekerjaan yang berat atau overload pada punggung bawah. ${ }^{6}$ Sedangkan pada perempuan juga bisa memiliki resiko tinggi akibat melakukan pekerjaan rumah dan berkaitan dengan terjadinya postmenopausal osteoporosis pada perempuan. ${ }^{7}$

Terdapat peningkatan prevalensi LBP pada rentangan umur 30 sampai 59 tahun dihubungkan dengan pekerjaan yang melebihi kapasitas (overload) pada usia produktif dan penyakit degeneratif pada usia yang lebih tua. ${ }^{8,9}$ Sedangkan pada individu berumur diatas 70 tahun kejadiannya menurun. Hal ini terjadi karena pada usia diatas 70 tahun biasanya terjadi penurunan aktifitas maupun pekerjaan lainnya sehingga dengan demikian terjadi pula penurunan resiko terjadinya LBP. ${ }^{8}$

Radiografi atau X-Ray sering menjadi pilihan pertama dan baik dilakukan jika ingin mengevaluasi adanya fraktur, deformitas tulang yang termasuk di dalamnya adalah perubahan-perubahan degeneratif seperti pembentukan osteofit, ketinggian corpus vertebra, dan lain sebagainya. ${ }^{10}$ Seperti yang ditemukan pada penelitian ini, temuan pada pemeriksaan radiologi berupa kelainan-kelainan yang terjadi pada tulang seperti osteofit, sklerotik end plate, kompresi corpus, listhesis, osteopenia, fraktur kompresi dan unstable back.

CT scan dapat menjadi pilihan modalitas pemeriksaan karena kemampuannya dalam menggambarkan tulang. Berdasarkan studi oleh Lateef dkk, pemeriksaan CT Scan dipertimbangkan untuk dilakukan pada pasien yang memiliki riwayat trauma karena dapat memvisualisasikan fraktur dengan baik. CT Scan juga sangat berguna dalam menilai fraktur kompresi pada vertebra. ${ }^{10}$ Pada penelitian ini, hanya sebanyak 1 orang (20\%) pasien LBP non trauma yang dirujuk melakukan pemeriksaan CT Scan, sebagian besar sampel yang dirujuk melakukan pemeriksaan CT Scan merupakan pasien LBP dengan riwayat trauma.

Pada penelitian ini didapatkan temuan radiologi pada pemeriksaan MRI didominasi oleh canal stenosis, spondylosis, degenerasi diskus yang meliputi protrusi dan bulging, dan kompresi nerve root. Hal ini serupa dengan penelitian oleh Dahal, dimana keabnormalitasan yang paling sering ditemukan pada pemeriksaan MRI adalah prolapse diskus atau bulging dan lumbar spondylosis. ${ }^{11}$

Proporsi tertinggi temuan radiologi pada MRI yang ditemukan pada penelitian ini adalah spinal canal stenosis yaitu sebesar 44,4\%. Penyebab tersering munculnya spinal canal stenosis adalah terjadinya herniasi diskus intervertebralis sehingga menyebabkan stenosis foramen, stenosis recessus lateralis atau canal spinalis itu sendiri yang kemudian menyebabkan kompresi nerve root atau spinal cord. Selain itu, hal yang bisa membuat canal menjadi semakin sempit adalah adanya perubahan dari corpus vertebra seperti pembentukan osteofit.

MRI menjadi pilihan pemeriksaan yang paling tepat apabila keluhan pasien LBP dicurigai berasal dari jaringan lunak atau soft tissue. Berdasarkan hasil temuan radiologi, herniasi diskus, kompresi nerve root, dan degenerasi diskus sering dikaitkan menjadi penyebab timbulnya keluhan low back pain. DDD atau degenerative disc disease dapat memperlihatkan beberapa temuan pada pemeriksaan MRI yaitu penyempitan spatium, perubahan intensitas sinyal dari spatium diskus, perubahan ligament maupun bone marrow, herniasi, osteofit, stenosis, dan lain sebagainya. ${ }^{11}$ Temuan-temuan tersebut juga terlihat pada penelitian ini yaitu osteofit, herniasi, spondylolisthesis, paravertebral muscle spasm, herniasi diskus, perubahan intensitas sinyal, dan kompresi medulla spinalis yang memiliki proporsi tinggi dan hipertrofi facet, fatty marrow changes, discitis, lesi ekstradural, dan soft tissue mass yang memiliki proporsi rendah pada penelitian ini.

\section{SIMPULAN}

Pada pemeriksaan Radiografi, ditemukan karakteristik temuan radiologis pada pasien LBP yaitu osteofit. Pada pemeriksaan CT Scan, yang menjadi modalitas utama pada pasien LBP dengan riwayat trauma, temuan radiologis pada pasien LBP didominasi oleh burst fracture, fraktur kompresi, dan fraktur prosessus spinosus. Karakteristik temuan radiologis yang ditemukan mendominasi pada pemeriksaan MRI adalah spinal canal stenosis.

\section{DAFTAR PUSTAKA}

1. Nicholas Henschke, Christopher G. Maher, Kathryn M. Refshauge. A Systematic Review Identifies Five "Red Flags" To Screen for Vertebral Fracture in Patients with Low Back Pain. Journal of Clinical Epidemiology. 2007; 61:110-118.

2. Sengkey L, Angliadi LS, Gessal J, Mogi TI. Diktat ilmu kedokteran fisik dan rehabilitasi. Manado: FK UNSRAT. 2006; h.79-90.

3. World Health Organization. Low Back Pain. 2010. Tersedia di: http://www.who.int/medicines/areas/priority_medicines/Ch6_24LBP.pdf.

4. Casazza Brian. Diagnosis and Treatment of Acute Low Back Pain. American Family Phycisian. 2012;85(4):p 343-350.

5. Qaseem Amir \& Kelft Eric. Appropriateness of Imaging in Chronic Low Back Pain.Springer International Publishing Switzerland. 2016

6. Punnett L, Pruss-Utun A, Nelson DI, Fingerhut MA, Leigh J, Tak S, dkk. Estimating The Global Burden of Low Back Pain Attributable to Combined Occupational Exposures. Am J Ind Med. 2005;48(6):459-69. 
7. Fernandez-de-las-Penas C, Hernandez-Barrera V, Alonso-Blanco C, Palacios-Cena D, Carrasco-Garrido P, Jimenez-Sanchez S, dkk. Prevalence of Neck and Low Back Pain in Community-Dwelling Adults in Spain: A Population-Based National Study. Spine (Phila Pa 1976). 2011;36(3):E213-9.

8. Dalke R, Gastal A, Muller N. Prevalence of Chronic Low Back Pain: Systematic Review. Rev Saude Publica. 2015;49:1.

9. Hoy D, Brooks P, Blyth F, Buchbinder R. The Epidemiology of Low Back Pain. Best Pract Res Clin Rheumatol. 2010;24(6):769-81.

10. Lateef H, Patel D. What is The Role of Imaging in Acute Low Back Pain. Musculoskelet Med. 2009; 2(2): 69-73.
11. Dahal S, Shahi RR, Joshi A, dkk. Spectrum of Lumbar Spine Pathologies in Patients with Low Back Pain on MR Examination: A Retrospective Hospital Based Study. Post Graduate Medical Journal of NAMS. 2012;12(2).

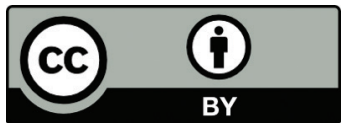

This work is licensed under a Creative Commons Attribution 